\title{
UJI AKTIFITAS TABIR SURYA DAN STABILITAS FISIK FORMULA GEL SEMPROT DARI EKSTRAK TEMUGIRING (CURCUMA HEYNEANA VAL.) DAN EKSTRAK KAYU MANIS (CINNAMOMUM BURMANII NEES.) DENGAN KOMBINASI KARBOPOL DAN HPMC.
}

\author{
Youstiana Dwi Rusita, Suhendriyo \\ Kementerian Kesehatan Politeknik Kesehatan Surakarta Jurusan Jamu
}

\begin{abstract}
Spray Gels, Sunscreens, Physical Stability, Rhizome Temugiring And Cortex Kayumanis. Excessive sun exposure can harm human skin, for skin damage can occur after exposure, namely in the form of burning or skin Erythema which is the onset of symptoms of degradation of cells and tissues. Sunscreen preparations have benefits to protect skin from exposure to ultraviolet rays and also contains antioxidants. Cinnamon (Cinnamomum burmanni Nees.) that has the activity of sunscreen, because it contains the compound sinamaldehid in addition also have activity as antioxidant. Rhizome temugiring (Curcuma Heyneana Val.) contain a flavanoid with fairly high antioxidant activity. Preparation of the gel has a number of advantages including not sticky and gels have a steady flow of tiksotropik and pseudoplastik i.e. solid gel when it is stored and will soon melt away when beaten. Spray technique is one of the new material has advantages which allow preparations sprayed with the dispersed evenly without needing to contact directly to flatten. Base that is often used in the making of gel karbopol and HPMC, among others. This type of Research design is a True Experiment. The formula that is used, there are three types with a combination of karbopol and HPMC. The research of spray gel extract kayumanis and extract temugiring on physical organoleptic stability Formula I red the typical smell of condensed form, kayumanis, part or a little murky, there are some air bubbles and cool on the skin when sprayed. Formula II, color of red brick the distinctive aroma preparations kayumanis, condensed form, no turbid and slightly cold when air bubbles, didispersikan to the skin; Test the viscosity Formula I 4000mPas, Formula II 1000 mPas, Formula III 1500mPas; Power test scatterplot latched into a Formula I attached did not drip to the formulation II is slightly attached and dripping, Formula III wasn't too attached to or flow; Test the spray pattern, the Formula I and II pattern that is formed is not round spread, Formula III pattern formed round spread; Its homogeneity test Formulation I, II, and III there are no particles; Irritation test Formulation I, II, and III the absence of symptoms of irritation. As for testing the stability of the antioxidant Formula I average IC50 values 1.21 SPF value average value, Formula II 10.48 IC50 value of 1.23 average average SPF 19.29, Formula III average IC50 values 1.18 SPF value average 12.51. Each formula no different IC50 values activity and SPF with the combination of karbopol and HPMC. Physical stability test and a good antioxidant formula III is with a combination of Karbopol 50\% and 50\% HPMC
\end{abstract}

Keywords: Spray Gels, Sunscreens, Physical Stability, Rhizome Temugiring And Cortex Kayumanis 
Abstrak: Gel Semprot, Tabir Surya, Stabilitas Fisik, Rimpang Temugiring Dan Kayumanis. Kayu manis (Cinnamomum Burmanni Nees.) yang memiliki aktifitas tabir surya, karena mengandung senyawa sinamaldehid selain itu juga memiliki aktifitas sebagai antioksidan. Rimpang temugiring (Curcuma Heyneana Val.) mengandung flavanoid dengan aktifitas antioksidan yang cukup tinggi. Sediaan gel mempunyai beberapa keuntungan diantaranya tidak lengket dan gel mempunyai aliran tiksotropik dan pseudoplastik yaitu gel berbentuk padat apabila disimpan dan akan segera mencair bila dikocok. Tehnik semprot merupakan salah satu sediaan baru yang mempunyai keuntungan dimana dengan teknik disemprot memungkinkan sediaan terdispersi secara merata tanpa perlu kontak secara langsung untuk meratakan. Basis yang sering digunakan dalam pembuatan gel antara lain karbopol dan HPMC. Jenis rancangan Penelitian ini adalah True Experiment. Formula yang digunakan ada 3 jenis dengan kombinasi karbopol dan HPMC. Hasil penelitian gel semprot ekstrak kayumanis dan ekstrak temugiring pada stabilitas fisik Uji organoleptik Formula I warna merah bau khas kayumanis, bentuk kental, sebagian atau sedikit keruh, ada gelembung udara sebagian dan dingin di kulit bila disemprotkan. Formula II, warna sediaan merah bata aroma khas kayumanis, bentuk kental, tidak keruh dan sedikit gelembung udara, dingin bila didispersikan ke kulit; Uji viskositas Formula I 4000mPas, Formula II 1000mPas, Formula III 1500 mPas; Uji daya sebar lekat Formula I melekat tidak menetes untuk formulasi II sedikit melekat dan menetes, Formula III tidak terlalu melekat atau mengalir; Uji pola semprot, Formula I dan II pola yang terbentuk adalah bulat tidak menyebar, Formula III pola yang terbentuk bulat menyebar; Uji homogenitas Formulasi I, II, dan III tidak ada partikel; Uji iritasi Formulasi I, II, dan III tidak adanya gejala iritasi. Sedangkan untuk uji stabilitas antioksidan Formula I nilai $\mathrm{IC}_{50}$ rata-rata 1,21 nilai SPF rata-rata 10,48 , Formula II nilai IC $_{50}$ rata-rata 1,23 nilai SPF rata-rata 19,29 , Formula III nilai $\mathrm{IC}_{50}$ rata-rata 1,18 nilai SPF rata-rata 12,51 . Tiap formula tidak ada beda aktifitas nilai IC $_{50}$ dan SPF dengan adanya kombinasi karbopol dan HPMC. Uji stabilitas fisik dan antioksidan yang baik adalah formula III dengan kombinasi Karbopol $50 \%$ dan HPMC 50\%

Kata Kunci : Gel Semprot, Tabir Surya, Stabilitas Fisik, Rimpang Temugiring Dan Kayumanis

\section{PENDAHULUAN}

Paparan sinar matahari yang berlebih dapat menimbulkan berbagai kerugian yaitu menyebabkan penuaan dini, merusak tekstur kulit, reaksi kulit terbakar serta memicu kanker kulit. Pencegahan bisa dilakukukan dengan menggunakan tabir surya, agar orang dapat memaksimalkan kesehatan dan kecantikan fisik (Kambade et al.,2012:72 dalam Gustiani, et al., 2015). Pentingnya sediaan kosmetik yang berbahan dasar ekstrak dari tanaman yang memiliki fungsi sebagai tabir surya sangat diminati oleh masyarakat karena adanya kekhawatiran terhadap efek samping penggunaan kosmetik berbahan dasar senyawa aktif tabir surya sintetik. Menurut Heinrich dkk. (2010) dan Ismail (2010) mengemukakan bahwa beberapa tanaman yang mengandung senyawa flavonoid dan fenolik mempunyai manfaat 
sebagai antioksidan juga diketahui mempunyai khasiat sebagai tabir surya, sehingga tanaman ini sangat berpotensi jika dibuat dalam bentuk kosmetik antioksidan dan tabir surya. Menurut penelitian ekstrak kulit delima mengandung kayaakan senyawa flavonoid, polifenol, asam fenolat, antosianin dan tannin diantaranya gallotannin, ellagitannin, asam ellagic, kuersetin, asam galat, katekin yang mempunyai khasiat sebagai antioksidan. Menurut penelitian Molyneux, (2004) salah satu sumber antioksidan alami terdapat pada kulit batang kayu manis. Kulit batang kayu manis mengandung senyawa yang memiliki aktivitas sebagai antioksidan yang kuat yaitu sinamaldehid. Losio merupakan sediaan kosmetika berupa emulsi yang mengandung air lebih banyak dari pada minyak. Sediaan ini memiliki beberapa sifat sebagai sumber pelembab bagi kulit, membuat tangan dan badan menjadi lembut dan mudah dioleskan. Berdasarkan latar belakang tersebut penulis tertarik untuk meneliti Aktivitas SPF sediaan losion kombinasi ekstrak kulit batang kayu manis dan kulit buah delima.

\section{METODE PENELITIAN}

Bahan Penelitian yaitu, Serbuk temugiring, serbuk kayumanis, karbopol, HPMC, trietanolamin, propilenglikol, metil paraben, propil paraben, etanol $70 \%$, etanol 96\%, natrium klorida, aquadest.

Alat Penelitian menggunakan Mortir stamper, timbangan analtik (ohaus), batang pengaduk, spatula, alumunium foil, beaker glass (pyrex), kaca arloji, buret, $\mathrm{pH}$ meter (Anatech), viscometer (Anatech), oven digital, lemari pendingin, botol semprot, plastik mika.
Analisis yang dilakukan adalah uji normalitas (Shapiro-Wilk). Untuk melihat hubungan antara kelompok perlakuan, jika data terdistribusi normal dan homogen dilakukan analisis varian satu arah (one way-ANOVA) dan uji Post Hoc Test. Jika data berdistribusi tidak normal, maka dilakukan analisis Kruskal-Wallis

\section{HASIL PENELITIAN}

Analisis yang dilakukan adalah uji normalitas (Shapiro-Wilk).Untuk melihat hubungan antara kelompok perlakuan, jika data terdistribusi normal dan homogen dilakukan analisis varian satu arah (one way-ANOVA).Jika data berdistribusi tidak normal, maka dilakukan analisis KruskalWallis. Hasil uji stabilitas aktifitas sediaan gel semprot ekstrak kayu manis dan temu giring sebagai antioksidan dengan nilai $\mathrm{IC}_{50}$ dan nilai SPF dilakukan pengamatan selama 4 minggu dan diperoleh data sebagai berikut

\section{Tabel 1}

\section{Hasil Uji Normalitas Nilai IC50dengan} Saphiro - Wilk

\begin{tabular}{ccccc}
\hline Uji & Formula & Minggu & $\begin{array}{c}\text { Nilai } \\
\boldsymbol{p} \text { - } \\
\text { value }\end{array}$ & Kesimpulan \\
\hline & & 1 & 1,000 & \\
& I & 2 & 0,637 & Normal \\
& & 3 & 1,000 & \\
\cline { 3 - 5 } IC $_{50}$ & & 4 & 1,000 & \\
& & 1 & 0,637 & \\
& & 2 & 0,637 & Normal \\
& & 3 & 0,637 & \\
& & 4 & 0,637 & \\
& & 1 & 1,000 & \\
& III & 2 & 0,637 & \\
& & 3 & 1,000 & \\
& & 4 & 0,637 & \\
\hline
\end{tabular}

Uji normalitas pada uji antioksidan dengan nilai $\mathrm{IC}_{50}$ menggunakananalisis Shapiro-wilk menunjukan bahwa data berdistribusi normal ( $p$-value $>0,05)$. Data 
ini adalah pengukuran nilai $\mathrm{IC}_{50}$ selama 4 minggu.

\section{Tabel 2}

\begin{tabular}{|c|c|c|c|c|}
\hline & $\begin{array}{r}\text { Hasil } \\
\text { deng }\end{array}$ & $\begin{array}{l}\text { ji Norr } \\
\text { n Saph }\end{array}$ & $\begin{array}{l}\text { alita } \\
\text { o-V }\end{array}$ & $\begin{array}{l}\text { Nilai SPF } \\
\text { ilk }\end{array}$ \\
\hline Uji & Formula & Minggu & $\begin{array}{l}\text { nilai } \\
p \text { - } \\
\text { value }\end{array}$ & Kesimpulan \\
\hline & & 1 & 0,637 & \\
\hline & & 2 & 0,637 & \\
\hline & 1 & 3 & 1,000 & Normal \\
\hline & & 4 & 0,463 & \\
\hline & & 1 & 1,000 & \\
\hline & & 2 & 1,000 & \\
\hline SPF & II & 3 & 0,274 & Normal \\
\hline & & 4 & 1,000 & \\
\hline & & 1 & 0,637 & \\
\hline & III & 2 & 0,056 & Normal \\
\hline & & 3 & 1,000 & Normal \\
\hline & & 4 & 0,463 & \\
\hline
\end{tabular}

Uji normalitas pada nilai SPF menggunakan analisis Shapiro-wilk menunjukan bahwa data berdistribusi normal ( $p$-value $>0,05)$. Data ini adalah pengukuran nilai SPF selama 4 minggu.

Uji normalitas pada nilai SPFmenggunakananalisis Shapiro-wilk menunjukan bahwa data berdistribusi normal ( $p$-value $>0,05)$. Data ini adalah pengukuran nilai SPFselama 4 minggu.Berikut ini merupakan hasil analisis yang menunjukkan aktifitas antioksidan dengan nilai $\mathrm{IC}_{50}$ dan nilai SPF pada formula I, formula II , dan formula III dengan variasi karbopol dan HPMC. Data yang didapatkan tidak homogeny perlu dilakukan uji N-Par analissi Kruskal Wallis Test. Analisis ini untuk mengetahui ada atau tidak ada pengaruh karbopol dan HPMC terhadap nilai $\mathrm{IC}_{50}$ dan nilai SPF pada sediaan gel semprot sebagai tabir surya dari ekstrak Kayumabis dan ekstrak temugiring

\section{Tabel 3}

Hasil Analisis Kruskal-Wallis Dengan Nilai IC50 dan SPF Pada Formula Gel Semprot Ekstrak Kayu Manis dan Ekstrak Temugiring Dengan Variasi Karbopol dan HPMC

\begin{tabular}{ccc}
\hline Uji & Nilai Sig. & Kesimpulan \\
\hline $\mathrm{IC}_{50}$ & 0,00 & Tidak ada beda \\
$\mathrm{SPF}$ & 0,00 & Tidak ada beda \\
\hline
\end{tabular}

\section{PEMBAHASAN}

Proses pertama setelah didapatkan serbuk simplisia adalah uji organoleptik pada serbuk simplisia kayu manis dan rimpang temugiring. Menurut Departemen Kesehatan RI (2000), pemeriksaan organoleptik bertujuan untuk pengenalan awal yang sederhana dan seobyektif mungkin menggunakan panca indera dengan mendeskripsikan warna, bau, bentuk, dan tekstur obyek yang diamati.Serbuk simplisia kayu manis dan rimpang temugiring masing-masing memiliki karakteristik yang berbeda.Serbuk simplisia kulit batang kayu manis memiliki karakteristik organoleptik dengan bentuk serbuk halus, warna coklat,dan aroma khas kayu manis. Sedangkan serbuk simplisia temugiring memiliki karakteristik organoleptik dengan bentuk serbuk halus, warna kumimg muda, dan memiliki aroma khas temugiring.

Penentuan kadar air berguna untuk mengetahui ketahanan suatu bahan dalam penyimpanannya dan merupakan cara penanganan terbaik bagi suatu bahan untuk menghindari pengaruh aktivitas mikroba (Mokoginta et al, 2013). Menurut Departemen Kesehatan RI (1986), serbuk simplisia harus memenuhi standar kadar 
air yang memenuhi persyaratan. Standar kadar air yang memenuhi persyaratan adalah tidak lebih dari $10 \%$. Berdasarkan perhitungan, kadar air serbuk simplisia kayumanisadalah $7,2 \%$ dan serbuk simplisia rimpang temugiring adalah 8,2 $\%$. Hasil tersebut menunjukkan bahwa serbuk simplisia masih memenuhi syarat standar kadar air serbuk. Bahan yang memiliki kadar air tinggi akan lebih mudah rusak karena produk tersebut menjadi media yang kondusif untuk pertumbuhan mikroorganisme. Bahan dengan kadar air rendah relatif lebih stabil selama proses penyimpanan daripada bahan dengan kadar air tinggi (Pardede et al, 2013).

Serbuk simplisia kayu manis dan rimpang temugiring dilakukan ekstraksi dengan cara maserasi menggunakan cairan penyari etanol $95 \%$ dan etanol $70 \%$. Pada proses maserasi cairan penyari akan menembus dinding sel dan masuk ke dalam rongga sel yang mengandung zat aktif yang akan larut, dan karena adanya perbedaan konsentrasi antara larutan zat aktifyang di dalam dengan di luar sel, maka larutan yang terpekat akan terdesak keluar, peristiwa tersebut akan berulang sehingga tercapai keseimbangan konsentrasi antara larutan yang di dalam dan di luar sel (BPOM, 1986).Etanol $70 \%$ dan $96 \%$ juga sangat efektif dalam menghasilkan jumlah bahan aktif yang optimal, dimana bahan penganggu hanya skala kecil yang turut ke dalam cairan pengekstraksi (Voight, 1994 dalam Juwita, 2013).

Hasil maserasi dari serbuk kulit batang kayu manis sebanyak 500 gram menghasilkan ekstrak 171,3gram dengan nilai randemen $34,30 \%$. Sedangkan hasil dari serbuk rimpang temugiring sebanyak 500 gram menghasilkan ekstrak 115, 35 gram dengan nilai randemen 23,07\%. Secara organoleptik ekstrak kayu manis berbentuk kental berwarna coklat kemerahan aroma khas kayu manis sedangkan untuk rimpang temugiring berbentuk semipadat berwarnakuning muda aroma khas temugiring. Ekstrak ini kemudian akan dibuat sebagai bahan aktif pembuatan sediaan gel semprot ekstrak kayu manis dan temu giring.

Pengujian stabilitas fisik sediaan gel semprot berdasarkan percobaan yang dilakukan oleh Susanti dkk., 2012 yaitu dengan penyimpanan gel semprot yang dihasilkan pada alat climatic chamber (27$30^{\circ} \mathrm{C}$ ) dalam waktu 1 bulan, dengan pengujian dilakukan setiap minggu dengan parameter fisik meliputi organoleptik yaitu warna, bau, bentuk, kekeruhan, gelembung udara, rasa dikulit, $\mathrm{pH}$, daya lekat sebar, daya pola semprot, homogenitas, viskositas.

Dari segi organoleptik penambahan $\mathrm{NaCl}$ mempengaruhi kekeruhan sediaan.Hal ini terjadi karena adanya daya hidrasi $\mathrm{NaCl}$ yang besar sehingga lebih larut dalam air dan mendesak ikatan karbopol dengan air. Interaksi molekul garam dengan molekul air menyebabkan penurunan kelarutan karbopol yang disebut dengan salting out (Zalts J.A. dalam Tristiana, Erawati, 2005). Penambahan larutan $\mathrm{NaCl}$ tiap formulasi berbeda yaitu antara $8 \mathrm{ml}$ sampai $13 \mathrm{ml}$ karena menghasilkan kekeruhan yang berbeda. Banyaknya gelembung udara dalam sediaan terbentuk setelah karnopol dinetralkan dengan basa. Hal ini disebabkan karena penambahan basa terhadap karbopol dilakukan segera setelah karbopol terdispersi dalam air. Menurut Ling Tong Joe (1968) polimer karbopol tidak memeiliki pengaruh terhadap pembentukan udara kecuali 
ketika dinetralkan, gel akan menjerat udara dan akan menghasilkan gelembung didalamnnya. Pada pembuatan gel semprot yang mengandung karbopol $100 \%$ memperlihatkan adanya gelembung meskipun hanya sebagian, hal ini karena jumlah karbopol banyak.Sedangkan untuk formula 3 yaitu mengandung karbopol $50 \%$ dan HPMC 50\% menghasilkan gelembung udara lebih banyak karena saat penambahan basis karbopol dan basis HPMC ada kesalahan yaitu basis karbopol belum seluruhnya menjadi transparan dan saat pencampuran terlalu banyak air yang ditambahkan sehingga menjadi lebih keruh dan banyak gelembung udara. Untuk menghindari pembentukan gelembung dapat dilakukan dengan cara penambahan basa yang dilakukan setelah karbopol terdispersi dalam air dan dibiarkan selama beberapa jam (Lin, Tong, Joe., 1968).

$\mathrm{pH}$ dapat diukur dengan menggunakan $\mathrm{pH}$ tester. Pada penelitian ini $\mathrm{pH}$ yang didapatkan sudah memenuhi syarat. Sediaan topical sebaiknya memiliki $\mathrm{pH}$ yang sesuai dengan $\mathrm{pH}$ kulit yaitu 4,5 - 6,5 (Budiman, 2008).

Homogenitas sediaan dapat dilihat dengan menggunakan kaca preparat dan didapatkan hasil bahwa tidak adanya partikel padat yang teradapat dalam gel, serta tidak adanya pembentuk gel yang masih menggumpal atau tidak merata dalam sediaan.

Viskositas sediaan yang beragam ditentukan oleh penambahan larutan $\mathrm{NaCl}$ ke dalam sediaan, penambahan $\mathrm{NaCl}$ yang terlalu banyak ke dalam gel karbopol akan menyebabkan salting out, oleh sebab itu $\mathrm{NaCl}$ yang ditambahkan kedalam gel sehingga viskositas gel yang kaku dan sangat kental tidak menurun dratis.
Hasil dari evaluasi pola penyemprotan dapat dilihat pada tabel di atas. Untuk Formula III, pola yang terbentuk bulat menyebar seperti pola ketika air disemprotkan sedangkan untuk formula I dan II pola yang terbentuk adalah bulat tidak menyebar, hanya berada pada satu titik lurus dari semprotan, berbentuk kecil dengan rata-ratadiameter $3 \mathrm{~cm}$. Tekanan yang dibutuhkan untuk menyemprotkan sediaan formula III paling sedikit karena viskositas formula III yang tidak terlalu tinggi, sedangkan pada formula lainnya dikarenakan viskositas yang terlalu tinggi pada formula I dan encerpada formula II, sehingga sediaan menjadi sulit untuk disemprotkan dan membutuhkan tekanan yang lebih besar dariformula III. Peningkatan kekuatan gel yang dihasilkan dari keadaan salting outpada polimer HPMC berpengaruh terhadap tekanan yang dibutuhkan, semakin kuat ikatan dalam suatu gel akan memungkinkan gel sulit disemprotkan dari alat semprot.Selain itu,peningkatan konsentrasi karbopol akanmeningkatkan viskositas dan meningkatkan tekanan yang dibutuhkan untuk menyemprotkan gel dari alat semprot bahkan mungkin sulit untuk disemprotkan (Kamishitta, Takuzo., et al., 1992)

Evaluasi Daya Sebar Lekat untuk formulasi II dan III tidak terlalu melekat atau mengalir dari daerah semprot karena viskositas yang lebih rendah dibandingkan formula I yang dapat melekat setelah disemprotkan di kulit lengan bagian atas lebih dari 10 detik, hal ini karena viskositas yang lebih tinggi sehingga sediaan lebih kental.

Uji iritasi dilakukan dengan responden 30 orang. Responden sebelumnya diberikan informasi terkait uji 
iritasi dan bagaimana cara mengetahui adanya iritasi atau tidak. Setiap responden diberikan lembar inform consent. Hasil yang didapat tidak ada yang iritasi.Hal ini ditandai dengan tidak adanya gejala iritasi seperti kulit merah ditempat gel yang disemprotkan, tidak panas dan tidak bengkak.

Hasil uji antioksidan dan aktifitas sebagai tabir surya bisa dilihat dengan nilai rata-rata pada Formula $\mathrm{I} \mathrm{IC}_{50}=1,12$ dan nilai $\mathrm{SPF}=10,48$, pada formula II nilai rata-rata pada Formula II $\mathrm{IC}_{50}=1,28$ dan nilai $\mathrm{SPF}=19,29$, nilai rata-rata pada Formula III $\mathrm{IC}_{50}=1,18$ dan nilai SPF $=12,50$. Nilai $\mathrm{IC}_{50}$ merupakan bilangan yang menunjukkan konsentrasi ekstrak (ppm) yang mampu menghambat proses oksidasi sebesar $50 \%$. Semakin kecil nilai $\mathrm{IC}_{50}$ berarti semakin tinggi aktivitas antioksidan (Zuhra et al, 2008). Menurut Wasitaatmadja (1997), sediaan dikatakan dapat memberikan perlindungan apabila memiliki nilai SPF 2-100 dan dianggap baik jika nilai berada di atas 15 .

Untuk mengetahui adanya pengaruh kombinasi HPMC dan karbopol terhadap stabilitas fisik dan aktifitas tabir surya maka data yang diperoleh perlu dianalisa dengan statistik. Pada pengamatan tiap minggu pada aktifitas antiosidan, pada Formula I dengan uji lavene menunjukkan nilai $\mathrm{p}>0,05$ yaitu 0,670 . Hal ini menunjukkan bahwa data tersebut homogen dan normal. Kemudian dilajutkan dengan uji ANOVA One Way dan menghasilkan nilai sig. 0,001 dimana nilai sig. $<0,05$ yaitu Ho ditolak yang berarti tidak ada perbedaan antara minggu I, II, III, IV pada nilai IC $_{50}$ untuk Formula I. Pada formula II menunjukkan hasil uji lavene nilai $p$-value $>0,05$ yaitu 1,00 . Hal ini menunjukkan bahwa data tersebut homogen dan normal. Kemudian dilanjutkan dengan uji ANOVA One Way dan menghasilkan nilai sig. 0,000 dimana nilai sig. $<0,05$ Ho ditolak yang berarti tidak ada perbedaan antara minggu I, II, III, IV pada nilai IC $_{50}$ untuk Formula II. Hasil uji lavene menunjukkan nilai $\mathrm{p}>$ 0,05 yaitu 0,702 . Hal ini menunjukkan bahwa data tersebut homogen dan normal. Kemudian dilanjutkan dengan uji ANOVA One Way dan menghasilkan nilai sig. 0,000 dimana nilai sig. $<0,05$ yang berarti tidak ada perbedaan antara minggu I, II, III, IV terhadap nilai IC $_{50}$ pada formula III

Untuk mengetahui apakah ada perbedaan tiap formula terhadap nilai SPF dan $\mathrm{IC}_{50}$ maka dilakukan uji Saphiro Wilk untuk mengetahui normalitas dan homogenitas data. Data yang didapat tidak normal dan homogen sehingga perlu dilakukan uji Kruskal Wallis, dan didapatkan data dengan nilai p- value < 0,05 yang berarti bahwa Ho ditolak atau Tidak ada beda tiap formula

\section{KESIMPULAN DAN SARAN}

Berdasarkan hasil penelitian uji stabilitas dan aktifitas gel semprot tabir surya ekstrak kayumanis dan ekstrak temugiring

1. Hasil sifat fisik sediaan gel semprot dari ekstrak Temugiring (Curcuma heyneana Val.) dan ekstrak Kayu Manis (Cinnamomum burmanii Nees.) dengan kombinasi Karbopol dan HPMC meliputi

a. Uji organoleptik

Pada formula I warna merah bau khas kayumanis, bentuk kental, sebagian atau sedikit keruh, ada gelembung udara sebagian dan dingin di kulit bila disemprotkan. Formula II, warna sediaan merah bata 
aroma khas kayumanis, bentuk kental, tidak keruh dan sedikit gelembung udara, dingin bila didispersikan ke kulit

b. Uji viskositas

Formula I $4000 \mathrm{mPas}$, Formula II 1000 mPas, Formula III 1500 mPas.

c. Uji daya sebar lekat

Formula I melekat tidak menetes untuk formulasi II sedikit melekat dan menetes, Formula III tidak terlalu melekat atau mengalir.

d. Uji pola semprot

Formula I dan II berbentuk bulat tidak menyebar, Formula

III berbentuk bulat dan menyebar.

e. Uji homogenitas

Semua formulasi tidak ada partikel

f. Uji iritasi

Formula I, II, III tidak menimbulkan iritasi

2. Aktivitas tabir surya dengan nilai $\mathrm{IC}_{50}$ dan SPF

Formula I nilai $\mathrm{IC}_{50}$ rata-rata 1,21 nilai SPF rata-rata 10,48 artinya aktifitas kuat

Formula II nilai $\mathrm{IC}_{50}$ rata-rata 1,23 nilai SPF rata-rata 19,29 artinya aktifitas kuat

Formula III nilai $\mathrm{IC}_{50}$ rata-rata 1,18 nilai SPF rata-rata 12,51 artinya aktifitas kuat

3. Berdasarkan uji statistik dengan uji normalitas dan homogenitas menggunakan Saphiro Wilk, sedangkan data yang tidak homogen dan tidak normal menggunakan Kruskal Wilk menunjukkan bahwa tiap formula tidak ada beda aktifitas nilai $\mathrm{IC}_{50}$ dan SPF dengan adanya kombinasi karbopol dan HPMC.

4. Formula yang memberikan stabilitas fisik dan antioksidan yang baik adalah formula III dengan kombinasi Karbopol 50\% dan HPMC 50\%

\section{DAFTAR RUJUKAN}

Fatmawati, A, Pakki Ermina, Mufida, Satriani. 2006. Uji Aktivitas Ekstrak Etanol Temugiring (Curcuma Heyneana Val.) sebagai Bahan Tabir Surya, Majalah Farmasi dan Farmakologi Vol. 10, No. 2.

Gibson, M. 2001. Pharmaceutical Preformulation and Formulation, 540-550, CRC Press, United States of America.

Herdiana, Y. 2007. Formulasi Gel Undesilenil Femilalanin dalam Aktivitas sebagai Pencerah Kulit. Skripsi, Fakultas Farmasi Universitas Padjajaran. Bandung. Hal 7

Holland, Troy., Hassan, Chaouk, Bruktawif Aswaf, Stephen Goodrich, Adrian Hunter, danVimala Francis. 2002. Spray Hidrogel Wound Dressing. United State Patent Aplication Publication.

Kamishitta, Takuzo, Takashi Miyazaki, YoshihideOkuno. 1992. Spray Gel Base and Sprau Gel Preparation Using There of. United State Patent Aplication Publication. Amerika.

Lieberman, Rieger and Banker. 1989. Pharmaceutical Dosage from: Disperse System. Vol. ke-2 New York: Marcel Dekker Inc. 495498. 
Miksusanti, E., dan S. Hotdelina. 2012. Aktivitas Antioksidan dan Sifat Kestabilan Warna Campuran Ekstrak Etil Asetat Kulit Buah Manggis (Garcinia mangostana L.) dan Kayu Secang (Caesalpinia sappan L.), Jurnal Penelitian SAINS, Vol. 15, No. 2, PP. 60-69.

Priani, Ega S., HumanisyaHaniva, Darusman, F. 2014. "Development of Sunscreen Emulgel Containing Cinnamomom Burmanni Stem Bark Extract, Internasional Journal of Science of Research (LJSR), Dess vol. 3, Issue $12 \mathrm{Hal}$.

Rismunandar dan Farry B. Paimin. 2001. Kayu Manis Budidaya dan Pengolahan Penebar Swadaya, Jakarta.

Rogers, T. L. 2009. Hypromellose, In: Rowe, R. C., Paul J. S., \& Marian E. Q. (eds.), $6^{\text {th }}$ Edition, 326-329, Hand Book of Pharmaceutical Excipient, Pharmaceutical Press. USA

Rowe, R. C., Shesky, P. J. \& Own, S. C. 2009. Hand Book of Pharmacentical Excipient $6^{\text {th }}$ Edition, Pharmaceutical Press and American Pharmacist Association, Washington USA.

Sari, D. M., et. al. 2015. Uji Aktifitas Tabir Surya Kulit Batang Kayumanis (Cinnamomum burmanni Nees ex BI) Secara In vitro. Prosiding Penelitian SPESIA.

Suardi M., Armenia \& Maryawati A. 2008, Formulasi dan uji klinik Gel Anti Jerawat Benzoil PeroksidaHPMC, Karya ilmiah, Fakultas Farmasi Universitas Andalas, Sumatra Barat.
Sudjoyo, TA., Mimin Honnasih, Yuanita Ratna P., 2012. Pengaruh konsentrasi Gelling Agent Carbomer 934 Dan HPMC Pada Formulasi Gel Lender Bekicot (Achatinafulica) terhadap kecepatan penyembuhan luka bakar pada punggung kelinci ., PHARMACON : JurnalFarmasi Indonesia Vol 13(1).

Vadas, E.B. (2000). Stability of Pharmaceutical products, in: Gennero, A.R., Ed., Remington The Science and Practice of Pharmacy, 20th ed., Lippincott Williams \& Wilkins, Philadelphia, Chap. 52

Voight, R., 1995, Buku Pelajaran Teknologi Farmasi, ditejemahkan oleh Soendari Noerono, Gajah Mada University Press, Yogyakarta.

Wade, Ainley, and Paul J. Weller.1994, Handbookof Pharmaceutical Recipient, second edition, American Pharmaceutical association, Washington.

Wasitaatmadja, S. M. 1997. Penuntun Ilmu Kosmetik Medik. Jakarta : Penerbit UI-Press

Wilkinson, J.B. 1982 Harry's Cosmeticologi7 Th Edition. PenerbitGeorge Godwin: London.

Wood, C \& Murphy E. 2000.Sunscreen effancy.globcosmet. Indo. Duluth, 5

Zuhra, C.F., Tarigan, J.B., Sihotang, H. 2008. Aktivitas antioksidan senyawa flavonoid dari daun katuk (Sauropus androgunus (L) Merr.). [Jurnal : Jurnal Biologi Sumatera: 7-10.]. Universitas Sumatera Utara. 